\title{
Bibliographic Analysis on the Financing of Education Reform in Morocco
}

\author{
Zineb Azar ${ }^{1}$, Oussama Dardary ${ }^{2}$, Malika Tridane ${ }^{3}$, Said Benmokhtar ${ }^{4}$, Said Belaaouad $^{5}$ \\ 1,2,3,4,5 Laboratory of Physical Chemistry of Materials LPCM \\ Ben M'Sik Faculty of Sciences \\ Hassan II University of Casablanca \\ Morocco \\ ${ }^{3}$ Regional Center for Education and Training Casablanca Anfa \\ BdBirAnzarane Casablanca \\ Morocco \\ azar.zineb@gmail.com
}

ABSTRACT: The National Charter for Education and Training in 1999 defined the principles, pillars and main objectives of the Moroccan education system, building on the various reforms of the early twenty-first century and the attempt to breathe new life into this reference document. Through partial and incremental changes, a total inability to tackle the root causes of the Moroccan education system and training has been revealed.

This research has been conducted to answer the questions of education in the foreground national concerns and priorities in the discourse of the main political actors in Morocco that have been raised and remain interesting and can be expressed in the following question: Morocco still fails to meet the challenge of educational reform, although a large part of the state budget is allocated to this sector. Should we increase funding for education or rather improve its governance and focus on accountability?

Keywords: Education, System, Morocco, Reform, Financing

Received: 14 April 2019, Revised 20 May 2019, Accepted 29 May 2019

DOI: $10.6025 /$ jet/2019/10/3/71-77

(C)2019 DLINE. All rights reserved

\section{Introduction}

After taking its independence, Morocco decided to go better than before. His Majesty King Mohammed V first attacked education reforms. Later, his successor, his majesty King Hassan II, declared forcefully in his throne speech that: "Our main concern is the reform of system education" (Hassan II, 1998). Since then, the reform of education was still an endless labyrinth, once entered the reform phase, it needed another before the end of the previous phase. Since the post-independence period, the record of education has been witnessed by numerous decisions and successive reforms that begin and end without evaluation of the achievement of its objectives. Almost a number of observers agree that education reform in Morocco requires a magic formula, given the unsatisfactory results achieved for decades. Despite the continuation of the reform plans, the results obtained remain 
unsatisfactory. The reform is not new, in fact his majesty King Hassan II had already stated in his 1996 throne speech, "The reform we are referring to ... is not limited to reviewing certain provisions of the Constitution. It is a global reform involving the sectors of administration, economy and education.

In addition, the National Charter for Education and Training in 1999 set out the principles, pillars and main objectives of the Moroccan education system, building on the various reforms of the early twenty-first century and the attempt to give new breath to this reference document. The education sector is considered a costly sector and the state is looking for a way out of its funding and is taking steps that weaken it rather than strengthening it according to the views of the followers, particularly with respect to the issue, outsourcing and encouraging the private sector in return for neglect in public schools. As our educational system expand in terms of additional courses and departments it is necessary to analyze the financial situation (1).

In this article, we first examine the status of the education sector, the low level of human capital development, and discuss some policy options and options to streamline the use of financial resources and improving efficiency of the education.

\section{Problematic}

Why has Morocco not been able to complete the education reform despite the succession of several plans and projects in this area, despite significant efforts at the financial level? Can current education policy and the draft framework law provide appropriate solutions to quantitative problems, the importance of combating imbalances in the management of the education sector? What role can diversification of funding sources and tuition fees have for households? Before answering these questions: What is the status of national education today?

\section{Education Sector Status: Old and Persistent Issues}

\subsection{The Deschooling in Morocco}

The generalization of education and its commitment to the quality and preservation of children at school have been at the heart of educational reform projects since the issuance of the National Charter for Education and Training, less on the alert for a decade. However, for the 2016-2017 school years, the percentage of school dropouts was estimated at 218141 , of which $51 \%$ were high school students, before the end of compulsory schooling1. We should add to these disturbing data a large number of repeaters, currently 813,000 students (including 420,000 in primary school)(2).

The Higher Council of Auditors analyzed the state of education in Morocco for the 2016-2017 academic year (2), and confirmed in this analysis the various imbalances, noting that about 50,000 departments and 22,000,000 students were studying in schools. Overcrowded sections: $16 \%$ in primary, $49 \%$ in high school, and $29 \%$ in high school qualifying (2).

In addition, 27,227 multi-level study departments were counted and the Supreme Audit Board estimated the shortage of teachers to 16,700 teachers (primary and secondary). Paradoxically, the school map showed a surplus of 1,405 teachers (because of the inability to finish their legal hours) (3).

\subsection{Low level of Academic Achievement}

In addition to the significant problems of school drop-out, repetition and imbalances in management and governance, many national and international evaluations have confirmed the very low level of achievement in terms of languages (reading and writing) and the level of scientific subjects.

The TIMSS (2003) and PIRLS (2006) tests have shown the poor results of Moroccan students in Science, Mathematics and Reading. For test scores (PIRLS) (for college and primary level) (PIRLS 2001), 74\% of Moroccan students do not reach the minimum level of success, as shown by a 2009 field study (PNEA) (Education in Morocco: Sector Analysis).

This deficit was documented in the report published by the World Bank (2017) and confirmed by a field study conducted by the Higher Council of Education, Training and Scientific Research (CSEFRS) in 2016: this field research has confirmed the existence of significant deficiencies in terms of language improvement and mathematics (4). It was noted that there was a generalized weakness in the results of academic achievement of arts and humanities students. In France, $84 \%$ of science students have reached a below average level and 54\% have not reached the 33\% threshold (PIRLS 2006: The reading skills of CM1 students). 
The basic lesson learned from the analysis of school drop-out data and low school achievement is that very large numbers of young people are not prepared to cope with social and professional life. This constitutes a structural obstacle to the integration of Moroccan youth and the economic development of the country. As a result, we face a fundamental deficiency in the country's development model.

For its part, the World Bank reportpublished a report on the situation in Morocco in 2017, entitled "Morocco to 2040: nonfinancial and economic prospects". This document presented an assessment of Morocco's status ten years after the 2007 memorandum.

This report shows progress in the country, but it remains essential in terms of economic results: the growth model. And the development of the education system: according to this report, about ten million Moroccans are still illiterate. What affects the economy as a whole: Morocco is seen as lagging development. Growth rates during the 2000s have been modest despite investment efforts, while the country's poor economic performance were mainly attributable to the low level of productivity and were also related to the deficit in the preparation of human capital.

All agree on the existence of structural imbalances in the national education sector, but it is important to pay attention to decisions and directions that may aggravate the situation.

\subsection{The Low Level of Human Capital Development}

The status of the national education sector is theoretically underdeveloped, even in relation to its neighbors. Morocco progressed in the medium term: it went from two years in 1982 to 5.64 in 2014 (5). This level is very low, even for countries in the Arab region, with Jordan at the intermediate level of 10 years of schooling. Most Arab countries are more than 7 years old on average (excluding Yemen and Mauritania). It is very evident that the average survival in the education system of most developed countries is 12 years and over.

A correct and accurate diagnosis is essential for the establishment of an educational policy and its adequacy. The diagnosis that we have briefly mentioned deserves to be taken into account when designing reform measures. Public education is no longer attractive and does not provide enough opportunities for families to invest more in education, as well as those who have the capacity to finance the education of their children. They have certainly placed them in the private sector, which translates into a ratio that varies between $15.60 \%$ for relatively well-to-do families and $31 \%$ for disadvantaged families in public spending on education by families(6). For example, the cost of returning to school in 1986 represented almost $29 \%$ of the average wage of poor families (B.CHEDATI, 1986).

What indicators do we have about state and family spending on education and what lessons can we draw from it?

\subsection{Field Research on Family Expenditures \& The National Education Account}

A field study conducted in 2013-2014(7) indicates that the average annual consumption expenditure per family was estimated at $76317 \mathrm{DHs}$, or about $6660 \mathrm{DHs}$ per month, the average expenditure rate being only $966 \mathrm{DHs}$ per month (no more than $723 \mathrm{DHs}$ in rural areas). Thus, one in two Moroccans lives with expenses equal to or less than this threshold.

Household spending is dominated by nutrition expenditure and 3.7\% of public spending on education is allocated in 2014 . This percentage varies considerably by social group: estimated at 137 dirhams for $20 \%$ of the least well-off households $(2,6 \%$ Household spending). And spending is estimated at 1,800 DHs (4.8\%) for $20 \%$ of the wealthiest families. Expenditures range from $114 \mathrm{DHs}$ for $10 \%$ of less affluent families (2.7\%) to $2680 \mathrm{DHs}(5.3 \%)$. For $10 \%$ of the wealthiest households, disparities in education spending by social group are enormous(7).

According to the National Education Account (published in 2015), education expenditure for 2012-2013 amounted to 69 billion dirhams, which represents the effort made by the national population to finance the education system. exclusion of data on higher education), $7.2 \%$ of gross domestic product, and this effort is equivalent to 1915 dirhams per person and 8690 dirhams per pupil (8). The distribution of financing resources between the public and private sectors is dominated by public finances (68\%), with households constituting the second largest source of financing after the state, i.e. $25 \%$ of public funding (around 15.8 billion). Barely represent $0.07 \%$ of public spending on education (8).

In terms of public spending on education, $48 \%$ of resources are financed by primary, followed by secondary school (21\%), 
secondary qualifying (19\%), pre-school education (4\%) and financial resources. are limited (8). The financing of families for education is allocated to primary education (57\%) followed by secondary education (19\%), hence $76 \%$ for these two levels of education, while $15 \%$ for secondary education. Only $9 \%$ is allocated to preschool level (Chedati. B; 2007).

The share of average expenditure guaranteed by public funding is relatively high, it is very high in some vocational training and higher education, and these courses are not within the reach of most Moroccan families. Making education pay will not solve even some of the problems of financing education in the country, in addition to the possibility of growing inequality.

The bill sets out a framework that will inevitably lead to increased funding for education. If the bill does not propose an appropriate solution, except a major risk, the efforts of Morocco to invest in the human capital (already low) of the country and social discrimination related to access to education.

\section{Proposals and Policy Options that can be Discussed}

The question of education has always been in the hands of the king's advisers. According to this bill, the Higher Council for Education, Training and Scientific Research will play a more influential role in the development of education policy. This will be at the expense of the government, the responsibility and the possibility of adopting other choices in educational policy. As a result, the Ministry of National Education will be reduced to a mailbox: it will be asked to prepare the "technical projects" to submit to the Supreme Council of Education, Training and Scientific Research. This council clearly has only an advisory role.

If it is not achieved for several decades, it is assumed that it will be resolved by the framework law in a few years. It is proposed to do this by adopting special plans in relatively short phases after the adoption of the framework law (3-6 years): The generalization of preschool education (3 years), quality, education of people with disabilities, special needs... It should be recalled that pre-school education was programmed in the National Charter for Education and Training in 2004. Despite the failure of the Charter and the Emergency Program in the previous decade, no order seems to have been drawn from the order of priorities and the gap between the design of the reform and its application.

The World Bank itself calls for us to be realistic and selective: "For education reform to be effective, it must be realistic and selective and it must deal with the major constraints of the use of" therapy of shock "to achieve a" miracle of education ", which significantly improves the level of Moroccan students.

The proposals contained in the draft framework law on governance mechanisms are qualified by the responsibility, the autonomy of educational institutions and the increase of the sense of responsibility. But the most worrying for the strategic interests of the country and Moroccans is that some of the proposals are ideological. And can lead to tragic results without solving the problems of the growing sector, as recommended by the adoption of tuition fees for the most accessible families in the sector of rehabilitation of secondary and higher education. This action can lead to results that hinder the development of education and human capital in the country, without being able to provide adequate funding to the sector.

\section{Low Financial Contribution Could Result in Considerable Damage}

It should be mentioned that the budget of the Ministry of National Education amounted to 54.4 billion in 2017(9). The share of this budget, in the state budget, was slightly increased (27\% in 2008 and $31 \%$ in 2011 ). Since then, this share has fallen to $18 \%$. The same goes for the share of the Ministry of Education's budget in gross domestic product, which increased from 5.5\% in 2010 to $4.4 \%$ in 2017.

The number of students was estimated at 6024721 in 2007-2008 (Analytical Report State \& Prospects of the Education \& Training System) and According to Mr. AMZAZI the Minister of National Education, this number rises to more than 7 million $(7,031,355)$ during the school year $2017-2018(10)$.

The daily ASSABAH reports, in its edition of Friday, February 15, 2019, that the head of a parents' association asserts that tuition fees are 500 dirhams per student are applied to $30 \%$ of the current number of students in secondary education, which remains a small sum. What does this amount represent in the financing of education? Even if it is decided to raise the cost to $1,000 \mathrm{DHs}$ (although the same family can have several children in secondary and higher education). With regard to political and 
social risks, this decision can have a devastating effect on the development of human capital already suffering from underdevelopment.

Since 2011, nearly $90 \%$ of the total budget of the Ministry of Education has been transferred to the AREFs, this rate currently exceeds $95 \%$. However, this strong fiscal decentralization faces a number of weaknesses, including the lack of qualified management skills. This leads to delays in budget commitments, which do not exceed $70 \%$ in the majority of institutions (11).

A report of the Court of Auditors, published at the end of 2016, had for example shown the "amateurism" of AREFs in the acquisition of teaching materials and chemicals over the period 2007-2014: random purchases, a hazardous management of inventories, government procurement not in compliance with the regulations in place (12).

There are serious and determined choices to fund education appropriately. The current situation and the many projects of the framework law call for very important possibilities: some choices can be made in terms of rationalization and the fight against the waste of available resources, and other choices that divert the mobilization of additional resources depend on taxation and national solidarity.

In Ukraine, At the pan-European level, the framework program "Competitiveness and Innovation" (CIP, 2007-2013) was adopted. This program is intended to promote the small and medium-sized enterprises innovative development. Program total budget amounted to 3621 million euros. Its successor was the Program for Competitiveness of Enterprises and SMEs (COSME) 20142020. One of the CIP components is the Entrepreneurship and Innovation Program (EIP), which aims to promote the development of inclusive education and entrepreneurship infrastructure (13).

The outcomes additionally proposed that specific financial attributes, for example, advanced education levels and abilities are essentials for successful changes in production. (14)

\subsection{Streamline the use of Financial Resources \& Improve Efficiency}

The cost of education and unit cost to high levels of school drop-out, and repetition that are based on the National Education Account (2013) database with a very significant contribution. The loss of resources is estimated at 7.42 billion dirhams, or $17.3 \%$ of public expenditure on education (Chedati. B; 2007).

In addition, there are several sources of funding. To be more productive, should not some of the tax expenditures be allocated to education? Finally, why does the state in particular not consider a solidarity tax on great wealth to promote human capital for development of the whole country?

\section{Conclusion \& Recommendations}

The political will must express its support for the development of the country by not targeting the poor incomes, the Moroccan families already contribute significantly to the expenditure devoted to education since the middle classes can finance the studies and direct their children towards a special education .

Public education has been abandoned because the public offer in the field of education has deteriorated in terms of reception conditions, quality and academic gains.

Expectations regarding the development of education financing at the expense of families remain limited: in 2018, the objective of increasing the proportion of private education set by the National Charter for Education and Training by $20 \%$ training (2000) was not applicable, simply because the majority of the population Those who did not drop out of public education suffer a terrible income shortage and the majority of those who are considered public school for a long time.

But the question still remains: how to develop an alternative education system capable of producing a more effective, quality and more profitable education?

Interest in the way education is funded, regardless of its quality, form, and the fact that the main burden is often on the state, particularly in terms of obtaining financial resources. However, there are several areas in which state dependence can be reduced and looking at things related to the model of education in general, which are, among others: 
- Adopt the concept of a productive school to increase its non-educational resources to others, while maintaining its scientific and cultural obligations to society, without neglecting the principle of free education.

- Examine the characteristics of the labor market, identify the requirements of occupations, qualifications and skills, and review current and future trends and directions in terms of quality of educator preparation, estimation of good job opportunities expected and the opportunity to market the educational specialties required for the labor market and development needs.

- Use co-financing and get rid of tax bureaucracies and their rigid principles by involving businessmen and companies in spending operations if, of course, we focus the country's attention on professional disciplines.

- Mobilize the enormous potential of civil society organizations.

The solutions of the Moroccan school crisis today encompass political, sociological and cultural dimensions that go beyond technical, administrative or financial aspects, which require a more global vision in an increasingly complex world. The Moroccan citizen, in all its colors and in all its categories, badly needs a qualitative education, developing a critical sense, because it can constitute an introduction to social unity and integration, thus putting an end to everything physical and symbolic waste and allowing a complete rebirth.

\section{Conflicts of Interest}

The authors declare that they have no conflicts of interest

\section{References}

[1] Selvakumar, V., Maran, K., Sankar, S. (2018). Perception on faculty academic relationship management in higher education with reference to self financing engineering colleges. International Journal of Engineering \& Technology, 7 (1.1), 2018 : 56-59.

[2] Referred by the First President of the Court of Auditors on the conditions of preparation and management of the new school year 2016/2017. Addressed to the Minister of National Education, Vocational Training, Higher Education and Scientific Research. In accordance with article 11 of the law 62-99 forming code of the financial jurisdictions.

[3] https://telquel.ma/2017/06/20/chiffres-choc-education_1551276, published $20 / 06 / 2017$, consulted 10/02/2019

[4] National Institute of Evaluation (INE at the Higher Council for Education, Training and Scientific Research (CSEFRS). Territorial Atlas of Disparities.2016

[5] http://www.maroc.ma/fr/actualites/hcp-le-taux-danalphabetisme-de-la-population-marocaine-baisse-de-deux-tiers-sur-un-demi ,published 2013,consulted 12/02/2019

[6] El Hous \& al .Expenditure in Moroccan secondary education at the expense of the State and families. Graduation thesis, COPE, Rabat. 1986

[7] https://www.leconomiste.com/article/1004160-37-des-depenses-des-menages-vont-l-alimentaire,published 28/10/2016,consulted 14/02/2019

[8] Activity report for the financial year . Presented to his MAJESTE LE ROI By Driss JETTOU First President of the Court of Auditors.2015

[9] https://telquel.ma/2017/10/27/budget-letat-en-2018-les-secteurs-bien-dotes-ceux-auraient-merite_1565882,published 27/10/ 2017, consulted 14/02/2019

[10] https://www.medias24.com/MAROC/Quoi-de-neuf/184572-Education-nationale-les-principaux-chiffres-de-l-annee-scolaire2017-2018.html ,published 16/07/ 2017, consulted 14/02/2019

[11] https://www.leconomiste.com/article/1038485-ecoles-et-universites-pretes-pour-1 autonomie, published 25/12/2018, consulted 14/02/2019

[12] Court of Auditors report (teaching materials), The approach to the implementation of the recommendations of the Court of Auditors and the proposals of the two general inspectorates of the Ministry concerning the management of teaching materials and chemicals.2017:3.

Journal of E - Technology Volume 10 Number 3 August 2019 
[13] Andrey,S., Sergii,V., Oksana, V. Inclusive Entrepreneurship Infrastructure, International Journal of Engineering \& Technology, 7 (3.2). 2018: 425-430

[14] Nadzifah, Y., \&al. Evaluation on Accessibility and Usage of Information and Communication Technology (ICT): Insights from Smallholders in Johor, Malaysia. International Journal of Engineering \& Technology, 7 (4.43) ,2018: 1-5 